\title{
Çarpıntı, Göğüs Ağrısı ve Senkop Yakınması Olan Çocukların Holter Kayıtları: Tek Merkez Deneyimi
}

\author{
Holter Records in Children with Palpitation, Chest Pain and \\ Syncope: Single Center Experience
}

Hüseyin YILMAZ, Fatih ŞAP, Muhammed GÜNEŞ, Emin ÜNAL, Mehmet Burhan OFLAZ, Tamer BAYSAL

Necmettin Erbakan Üniversitesi, Meram Tıp Fakültesi, Çocuk Sağlığı ve Hastalıkları Anabilim Dalı, Çocuk Kardiyoloji Bilim Dalı, Konya, Türkiye

\section{ÖZ}

Amaç: Hastalar ve aileleri için endişe verici yakınmalardan olan çarpıntı, göğüs ağrısı ve senkop gibi belirtiler kalp ritim bozukluklarının habercisi olabilmektedir. Altta yatan ciddi ritim bozukluklarının tanısında elektrokardiyografi (EKG) bazen yetersiz kalabilmektedir. Bu çalışmadaki amacımı çarpıntı, göğüs ağrısı ve senkop yakınması ile gelen çocuk hastalarda 24 saatlik ritim Holter inceleme sonuçlarının sunulmasıdır.

Gereç ve Yöntemler: Kliniğimize Ocak 2016 - Ocak 2018 tarihleri arasında çarpıntı, göğüs ağrısı ve senkop şikayeti ile başvuran 450 çocuk hastanın anamnez, fizik muayene bulguları, EKG, ekokardiyografi (EKO) ve 24 saatlik ritim Holter kayıtları geriye dönük olarak değerlendirildi.

Bulgular: Çalışmaya alınan hastaların 240'ı (\%53.3) kız, 210’u (\%46.6) erkekti. Hastaların yaşları 3-18 yaş arasında

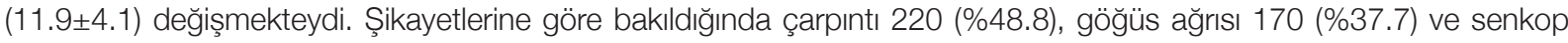
60 (\%13.1) hastada vardı. Elektrokardiyografide aritmi sıkığı \%6.6 (30/450) saptanmakta iken bunlardan 9 hastada supraventriküler ektopik atım (SVE) ve 21 hastada ventriküler ekstra atım (VES) olduğu görüldü. Yapılan EKO'ların 64'ünde (\%14.9) konjenital veya edinsel kalp hastalığı olduğu tespit edildi. Patolojik EKO bulguları olan 64 hastanın 18'inin (\%28) 24 saatlik ritim Holter kayıtlarında aritmi vardı. 24 saatlik ritim Holter kayıtlarında toplam aritmi sıklığı \%34.6 (156/450) saptandı; bunların 65'inde SVE, 84'ünde VES, üçünde supraventriküler taşikardi (SVT) ve dördünde ventriküler taşikardi (VT) görüldü. Aritmi görülme sıklığı senkoplu (\%51.6) hastalarda çarpıntısı (\%31.3) ve göğüs ağrısı (\%32.9) olanlara göre anlamlı olarak daha fazla saptandı.

Sonuç: Çarpıntı, göğüs ağrısı ve senkop gibi yakınmalarla aritmi görülme sıklığı senkoplu hastalarda çarpıntısı ve göğüs ağrısı olanlara göre anlamlı olarak daha fazla saptandı.

Anahtar Sözcükler: Aritmi, Çocuk, Göğüs ağrısı, Senkop

\section{ABSTRACT}

Objective: Symptoms such as palpitations, chest pain and syncope, which are among the worrying complaints for patients and their families can be the precursor of heart rhythm disorders. Electrocardiography (ECG) is sometimes insufficient in the diagnosis of underlying serious rhythm disorders. The aim of our study was to present 24-hour Holter monitoring examination results in pediatric patients presenting with palpitations, chest pain and syncope.

Material and Methods: Anamnesis, physical examination findings, ECG, echocardiography (ECHO) and 24-hour

(1)

YILMAZH : :0000-0002-9971-9669

SAPF

GÜNEŞ M

ÜNALE

$: 0000-0002-8739-4553$

: 0000-0003-1515-4654
Çıkar Çatışması / Conflict of Interest: Tüm yazarlar adına, sorumlu yazar çıkar çatışması olmadığııı belirtir.

Etik Kurul Onayı / Ethics Committee Approval: Bu çalıșmada ulusal ve uluslararası etik kurallara uyulmuștur. Bu çalıșma için Necmettin Erbakan Üniversitesi Meram Tıp Fakültesi, Illaç ve Tıbbi Cihaz Dışı Araştırmalar etik kurulundan onay alındı (20.09.2019 tarihli 2019 / 2089 karar). Kayıt sırasında veliler tarafından araştırmaya katıım için bilgilendirilmiş bir onay imzalanmıştır.

Yazarların katkısı / Contribution of the Authors: YILMAZ H: Araștırma ve/veya makalenin hipotezini veya fikrini olușturan, Sonuçlara ulașmak için planlama/ metodoloji belirleme, Çalısmanın bütününün veya önemli bölümlerinin yazımında sorumluluk almak. SAP F: Araștırma ve/veya makalenin hipotezini veya fikrin olușturan, Sonuçların mantıksal olarak Yorumlanması ve sonuçlandırılması, Çalıșmanın bütününün veya önemli bölümlerinin yazımında sorumluluk almak. GÜNEŞ M: Hasta takibinde sorumluluk almak, ilgili biyolojik malzemelerin toplanması, veri yönetimi ve raporlama, deneylerin yürütülmesi, Çalışma için gerekli literatür taramasında sorumluluk almak. ÜNAL E: Hasta takibinde sorumluluk almak, ilgili biyolojik malzemelerin toplanması, veri yönetimi ve raporlama, deneylerin yürütülmesi, Çalışma için gerekli literatür taramasında sorumluluk almak. OFLAZ MB: Sonuçlara ulaşmak için planlama/metodoloji belirleme, Araştırma/çalıșmanın sorumluluğunu üstlenmek, ilerlemenin seyrini denetlemek, Yazım ve dilbilgisi dıșında bilimsel olarak gönderilmeden önce makaleyi gözden geçirme. BAYSAL T: Araștırma/çalıșmanın sorumluluğunu üstlenmek, ilerlemenin seyrini denetlemek, Sonuçların mantıksal olarak Yorumlanması ve sonuçlandırlması.

Atıf yazım şekli / How to cite : Yılmaz H, Şap F, Güneș M, Ünal E, Oflaz MB, Baysal T. Çarpıntı, Göğüs Ağrısı ve Senkop Yakınması Olan Çocukların Holter Kayıtlarının İncelenmesi. Türkiye Çocuk Hast Derg 2021;15:192-197.
Yazışma Adresi / Correspondence Address:

Hüseyin YILMAZ

Necmettin Erbakan Üniversitesi, Meram Tıp Fakültesi, Çocuk Sağlığı ve Hastalıkları Anabilim Dalı, Çocuk

Kardiyoloji Bilim Dalı, Konya, Türkiye

E-posta: hoyilmaz42@gmail.com
Geliş tarihi / Received : 17.02.2020 Kabul tarihi / Accepted : 01.06.2020 Elektronik yayın tarihi : 28.09.2020 Online published

DOI: 10.12956/tchd.688288 
Holter recordings of 450 children, who were admitted to our clinic between January 2016 and January 2018 with palpitations, chest pain and syncope were evaluated retrospectively.

Results: Of 450 patients included in this study, 240 (53.3\%) were female and 210 (46.6\%) were male. The ages of the patients ranged

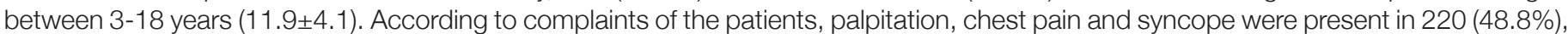
$170(37.7 \%)$ and $60(13.1 \%)$ cases, respectively. When ECGs of the patients were evaluated, the frequency of arrhythmias was $6.6 \%$ (30/450): 9 patients had supraventricular ectopic beats (SVE) and 21 patients had ventricular extrasystoles (VES). Congenital or acquired heart diseases were detected with ECHO in 64 (14.9\%) of the patients. Eighteen (28\%) of 64 patients with pathological ECHO findings had arrhythmias. In 24-hour Holter recordings, the frequency of total arrhythmias was found to be 34.6\% (156/450); SVE, VES, SVT and VT were seen in 65, 84, 3 and 4 patients, respectively. The incidence of arrhythmia was significantly higher in patients with syncope (51.6\%) than palpitations (31.3\%) and chest pain (32.9\%).

Conclusion: In children with palpitations, chest pain and syncope, sometimes the underlying cause can not be detected clearly with history taking, physical examination and ECG. Therefore in this condition, we thought that it would be better to perform 24-hour Holter monitoring in order to avoid overlooking arrhythmias that may cause life-threatening conditions.

Key Words: Arrhythmia, Chest pain, Child, Syncope

\section{GiRiş}

Hastalar ve aileleri için çarpıntı, göğüs ağrısı ve senkop belirtileri oldukça endişe verici olduğundan çocuk acil servisine sık başvuru sebeplerindendir. Her ne kadar bu yaygın semptomlar için kalp nedenleri nadir olsa da, tanı konulmaması bazen ölümle sonuçlana Eilmektedir (1). Çocuklarda görülen aritmilerin belirtive bulguları yașa göre değişim gösterebilir. Bazen ciddi aritmisi olan çocuğun fizik muayene bulguları tamamen normal olabileceği gibi çarpıntı, senkop, göğüs ağrısı veya dispne gibi yakınmalarla doktora başvurabilirler (2). Kalp ritminde kısa süreli olan azalma, artma veya duraklamalar şeklindeki düzensizlikler EKG ile tespit edilemeyebilir (3). Bunun için daha uzun süreli kayıt alabilen 24 saatlik ritim Holter monitorizasyonu semptom veren veya vermeyen ritim bozukluklarını tespit edilmesinde EKG'ye göre daha üstündür (4). Çocuklarda ciddi ritim bozuklukları nadir olsa da, son zamanlarda yapılan bir prevalans çalışmasında ilkokul öğrencilerinin \%1.2'inde ve ortaokul öğrencilerinin \%2.3'ünde aritmi veya iletim anormalliklerinin olduğu bildirilmektedir (5). Primer kardiyak aritmilere bağlı ani ölümler diğer kardiyak sebeplere göre on kat fazla görülmektedir ve ölümler sıklikla fiziksel aktivite veya spor karşılaşmaları esnasında olmaktadır ve bu oran yaş ile artmaktadır (6).

Bu çalışmada çarpıntı, göğüs ağrısı ve senkop gibi yakınmalarla polikliniğe başvuran çocuk olgularda öykü, fizik muayene ve klasik EKG incelemeleri yanında 24 saatlik ritim Holter kaydı sonuçlarının geriye dönük olarak incelenmesi amaçlandı.

\section{GEREÇ ve YÖNTEMLER}

Çalışmamıza Ocak 2016-Ocak 2018 tarihleri arasında Çocuk Kardiyoloji Polikliniği'ne çarpıntı, göğüs ağrısı ve senkop şikayetlerinden en az birisi ile başvuran 450 çocuk hasta alındı. Hasta verileri dosya kayıtlarında retrospektif olarak incelenerek elde edildi. Daha önceden bilinen ritim bozukluğu tanısı olanlar ve konjenital/edinsel kalp hastalığı olan olgular çalışma dışı bırakıldı. Öykü, fizik muayene bulguları, EKG, EKO ve 24 saatlik ritim
Holter verileri kaydedildi. Elektrokardiyografi kayıtları üç kanallı 12-derivasyonlu EKG cihazı (Nihon Cohden Cardiofax, Japan) ile elde edildi. Elektrokardiyografide; hız, PR ve QTc ölçümleri yanında patolojik veriler kaydedildi. Ekokardiyografide; klasik iki boyut ve M-mod sonuçlar ile patolojik yapısal ve fonksiyonel veriler kaydedildi. Çalışmada üç kanallı 24 saatlik ritim Holter (CardioScan II Holter analysis, USA) kayıt cihazı kullanıldı. Yirmi dört saatlik ritim Holterde; hı (minimum, maksimum ve ortalama), PR ve QTc ölçümleri ile patolojik veriler kaydedildi.

Bu çalışma için Necmettin Erbakan Üniversitesi Meram Tıp Fakültesi, llaç ve Tıbbi Cihaz Dışı Araștırmalar etik kurulundan onay alındı (20.09.2019 tarihli 2019 / 2089 karar).

İstatistiksel analiz için SPSS 19.0 paket programı kullanıldı. Elde edilen verilerin dağıımına bakıldıktan sonra ortalama $\pm S D$ veya ortanca (minimum ve maksimum) ve yüzde olarak sonuçlar özetlendi. Çalışmada bağımsı gruplarda t testi, bağımlı gruplarda tek yönlü ANOVA testi, sayısal değerlerinin normal dağılıma uygunluğu ShapiroWilks testi ile incelendi. Kategorik değişkenler arasında farklılıkların incelenmesinde Pearson Ki kare (Pearson Chi- Square), Yates Ki kare (Continuity Correction) ve Fisher Exact testten (Fisher's Exact Test) uygun olan yöntem sonuçları verildi. İstatistiksel olarak $p<0.05$ olması anlamlı kabul edildi.

\section{BULGULAR}

Çalışmaya alınan toplam 450 hastanın 240'ı (\%53.3) kız ve 210 'u (\%46.6) erkekti. Hastaların yaş ortalaması $11.9 \pm 4.1$ yıl (3-18yaş)'dı. Kızların yaş ortalamaları erkeklerden anlamlı olarak yüksekti (sırasıly $12.62 \pm 3.96$ yll; $11.23 \pm 4.31$ yll) $(p<0.05)$. Göğüs ağrısı olan hastaların yaş ortalamaları $(11.46 \pm 4.35$ yıl) çarpıntı (11.46 \pm 4.35 yll) ve senkop $(13.10 \pm 3.87)$ şikayeti olanlarla benzerdi. Fakat senkop şikayeti olan grubun yaş ortalaması çarpıntı olanlardan istatistiksel olarak yüksek saptandı $(p=0.021)$

Başvuru şikayetlerine göre bakıldığında çarpıntı \%48.8 (220/450), göğüs ağrısı \%37.7 (170/450) ve senkop \%13.3 
Tablo I: Olguların elektrokardiyografi (EKG) ve 24 saatlik ritim Holter ölçüm değerleri.

\begin{tabular}{|c|c|c|c|}
\hline & $\begin{array}{c}\text { Çarpıntı }(n=220) \\
(O r t \pm S D)\end{array}$ & 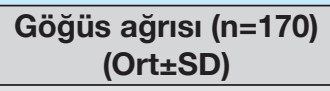 & $\begin{array}{c}\text { Senkop }(n=60) \\
(\text { Ort } \pm \text { SD) }\end{array}$ \\
\hline EKG HIz (/dk) & $85 \pm 14.9$ & $81.8 \pm 14.4$ & $78.9 \pm 14.1$ \\
\hline EKG; QTc (ms) & $393.5 \pm 21.0$ & $395.6 \pm 22.8$ & $391.4 \pm 24.4$ \\
\hline Holter; Minimum Kalp hızı (/dk) & $55 \pm 10$ & $52 \pm 9$ & $51 \pm 9$ \\
\hline Holter; PR (ms) & $132.4 \pm 14$ & $134.8 \pm 16$ & $134 \pm 17.3$ \\
\hline Holter; QTc (ms) & $401 \pm 16.6$ & $403.5 \pm 17$ & $404.3 \pm 15.3$ \\
\hline
\end{tabular}

Tablo II: Olguların muayene ve ekokardiyografi bulguları.

\begin{tabular}{|c|c|c|c|}
\hline & $\begin{array}{c}\text { Çarpıntı }(n=220) \\
\text { (Ort } \pm \text { SD) }\end{array}$ & $\begin{array}{c}\text { Göğüs ağrısı (n=170) } \\
\text { (Ort } \pm \text { SD) }\end{array}$ & $\begin{array}{c}\text { Senkop }(n=60) \\
\text { (Ort } \pm \text { SD) }\end{array}$ \\
\hline Yaş (Yıl) & $11.4 \pm 4.3$ & $12.2 \pm 3.9$ & $13.1 \pm 3.8$ \\
\hline Kalp Tepe Atımı (/dk) & $83 \pm 13.8$ & $80 \pm 11$ & $78 \pm 12$ \\
\hline Sistolik Tansiyon (mmHg) & $104.4 \pm 8.7$ & $105.8 \pm 7.9$ & $106 \pm 8.2$ \\
\hline Diyastolik Tansiyon (mmHg) & $65.7 \pm 6.6$ & $67.2 \pm 6.6$ & $67 \pm 7.6$ \\
\hline LA/Aort & $1.2 \pm 0.1$ & $1.2 \pm 0.1$ & $1.1 \pm 0.1$ \\
\hline IVSd (mm) & $7.3 \pm 11.5$ & $7.6 \pm 1.4$ & $7.6 \pm 1.3$ \\
\hline LVPWd (mm) & $7.1 \pm 1.5$ & $7.4 \pm 1.3$ & $7.4 \pm 1.2$ \\
\hline LVEDd (mm) & $39.2 \pm 5.9$ & $40.8 \pm 5.2$ & $41 \pm 5.2$ \\
\hline
\end{tabular}

LA: Sol atriyum, IVSd: intraventriküler septum kalınlı̆̆ı, LVPWd: Sol ventrikül arka duvar kalınlığı, LVEDd: Sol ventrikül diastol sonu genişliği, LVESd: Sol ventrikül sistol sonu genişliği, EF: Ejeksiyon fraksiyonu, FS: Kısalma fraksiyonu

(60/450) oranında saptandı. Göğüs ağrısı, çarpıntı ve senkop şikayetleri ile gelen hastaların K/E oranları benzerdi ( $p=0.529$ ). Hastaların 416'sında (\%92.4) kalpte dinlemekle ek ses veya üfürüm yoktu. Oskültasyonda duyulan üfürüm yüzdeleri açısından (çarpıntl; \%8.1, göğüs ağıısı; \%5.8 ve senkop; \%10) gruplar arasında anlamlı fark saptanmadı $(p=0.517)$. Tüm hastaların periferik nabızları normal olarak alındı, ayrıca siyanoz ve ödem saptanmadı.

Elektrokardiyografi incelemelerinde QRS aksl; \%97 normal, \%1.1 sağ, \%1.3 sol ve \%0.2 kuzeybatı aks olarak saptandı. Yakınmalarına göre klasik EKG ve 24 saatlik ritim Holter ölçümleri Tablo I'de sunulmuştur. Patolojik EKG verileri; supraventriküler ektopik atım (SVE) 9 (\%2) olguda ve ventriküler ekstra atım (VES) 21 (\%4.6) hastada görüldü. Elektrokardiyografilerinde taşiaritmi veya bradiaritmi saptanmadı. Cinsiyetler arasında SVE görülme açısından anlamlı bir fark yok iken ( $p=0.893)$, VES erkeklerde daha sık olduğu görüldü ( $p=0.02)$. Çarpıntı ve göğüs ağrısı şikayeti ile başvuranlarda EKG'de VES görülme oranı SVE'den daha fazla olduğu görüldü. Senkop şikayeti olanlarda VES görülmez iken bir olguda SVE saptandı. Elektrokardiyografide ST/T değişikliği sadece göğüs ağrısı şikayeti olan çocukların beşinde (\%2.9) tespit edildi. ST/T değişikliği açısından cinsiyetler arasında belirgin bir fark yoktu.

Ekokardiyografi incelemelerinde olguların \%14.9'unda (64/450) konjenital veya edinsel kalp hastalığı olduğu tespit edildi. Çarpıntı şikayeti olan çocukların 37'sinde (\%16.8), göğüs ağrısı olanların 21'inde (\%12.3) ve senkopu olanların 6'sında (\%10) patolojik EKO bulguları olduğu görüldü. Patolojik EKO bulguları olan hastalarımızda klinik olarak önemli olmayan küçük septal defektler (atriyal veya ventriküler) veya hafif romatizmal/ konjenital kapak hastalığı saptandı. Olguların genel özellikleri ve klasik EKO ölçümleri Tablo II'de sunulmuştur. Patolojik EKO bulguları olan 64 hastanın 18'inde (\%28.1), 24 saatlik ritim Holter'de aritmi vardl.

Hastaların 24 saatlik ritim Holter'leri incelendiğinde; \%34.6 (156/450) oranında aritmi olduğu belirlendi. Aritmi oranı çarpıntı ile gelen çocuklarda \%31.3 (69/220), göğüs ağrısı ile gelenlerde 
Tablo III: Başvuru yakınmasına göre aritmi saptanan olgular.

\begin{tabular}{l|c|c|c|c|}
\hline & $\begin{array}{c}\text { Çarpıntı } \\
(\mathbf{n = 2 2 0}\end{array}$ & $\begin{array}{c}\text { Göğüs ağrısı } \\
(\mathbf{n = 1 7 0 )}\end{array}$ & $\begin{array}{c}\text { Senkop } \\
(\mathbf{n = 6 0 )}\end{array}$ & $\begin{array}{c}\text { Toplam } \\
(\mathbf{n}=\mathbf{4 5 0})\end{array}$ \\
\hline EKG; SVE (n) & 4 & 4 & 1 & 9 \\
\hline EKG; VES (n) & 8 & 13 & -- & 21 \\
\hline Holter; SVE (n) & 24 & 25 & 16 & 65 \\
\hline Holter; SVT (n) & 3 & -- & -- & 3 \\
\hline Holter; VES (n) & 40 & 30 & 14 & 84 \\
\hline Holter; VT (n) & 2 & 1 & 1 & 4 \\
\hline
\end{tabular}

SVE: Supraventriküler ektopik atım, VES: Ventriküler esktrasistol, SVT: Supraventriküler taşikardi, VT: Ventriküler tașikardi

Tablo IV: Olguların cinsiyetlerine göre başvuru şikayetleri, genel özellikleri ve anormal elektrokardiyografi(EKG)/24 saatlik ritim Holter verilerinin dağıımı.

\begin{tabular}{|c|c|c|c|}
\hline & Kız n (\%) veya ort \pm SD & Erkek $n(\%)$ veya ort \pm SD & p \\
\hline Yaş (Yıl) & $12.6 \pm 3.9$ & $11.2 \pm 4.3$ & $<0.001$ \\
\hline Çarpıntı & $121(55)$ & $99(45)$ & 0.529 \\
\hline Göğüs ağrısı & $85(50)$ & $85(50)$ & 0.529 \\
\hline Senkop & $34(56.6)$ & 26(43.3) & 0.529 \\
\hline EKG SVE & $5(55.6)$ & $4(44.4)$ & 0.893 \\
\hline EKG VES & $6(28.5)$ & $15(71.4)$ & 0.020 \\
\hline Holter SVE & 32(49.2) & 33(50.2) & 0.297 \\
\hline Holter VES & $41(48.8)$ & $43(51.2)$ & 0.184 \\
\hline Holter SVT & 1(33.3) & 2(66.6) & 0.484 \\
\hline Holter VT & $3(75)$ & $1(25)$ & 0.800 \\
\hline Kalp Tepe Atımı (/dk) & $82 \pm 13.2$ & $81 \pm 12.6$ & 0.450 \\
\hline Sistolik Tansiyon (mmHg) & $105.4 \pm 8.3$ & $104.8 \pm 8.4$ & 0.434 \\
\hline Diyastolik Tansiyon (mmHg) & $66.9 \pm 6.6$ & $65.9 \pm 6.9$ & 0.120 \\
\hline $\mathrm{O}_{2}$ Saturasyonu $(\%)$ & $97.8 \pm 1$ & $97.8 \pm 1$ & 0.519 \\
\hline
\end{tabular}

SVE: Supraventriküler ektopik atım, VES: Ventriküler esktrasistol SVT: Supraventriküler taşikardi, VT: Ventriküler taşikardi

\%32.9 (56/170) ve senkoplularda \%51.6 (31/60) olarak tespit edildi. Bu üç gruptan senkop ile başvuranlarda aritmi görülme sıklığı çarpıntı ve göğüs ağıısı ile başvuranlardan anlamlı olarak daha fazlaydı $(p=0.011)$.

Çarpıntısı olan olguların 24 saatlik ritim Holter'lerinde; VES \%18.1 (40/220) ve SVE \%10.9 (24/220) oranında, göğüs ağrısı olanlarda; VES \% $17.6(30 / 170)$ ve SVE \%14.7 (25/170) oranında ve senkoplularda; VES \% 23.3 (14/60) ve SVE \%26.6 (16/60) oranında olduğu görüldü. Çarpıntı şikayeti ile başvuran olguların üçünde (\%1.3) non-sustained (kısa süreli) supraventriküler taşikardi (SVT) görülürken, göğüs ağrısı ve senkop nedeni ile başvuranlarda SVT görülmedi. Non-sustained ventriküler taşikardi (VT) her üç grupta da birer hastada görülürken, sustained (uzun süreli) VT çarpıntı şikayeti ile başvuran bir hastada tespit edildi (Tablo III). Tablo IV'te tüm hastaların verilerinin cinsiyetlere göre dağılımı görülmektedir. Erkek hastalarda EKG'de VES saptanma sıklığı kızlara göre anlamlı yüksek saptanırken, başvuru semptomları ve diğer aritmilerin dağlımı hem EKG hem holter analizinde benzer bulundu.

\section{TARTIŞMA}

Çocuklarda aritmiye bağlı klinik bulgular altta yatan ritim bozukluğuna ve başvuru sırasında hastanın yaşına bağlı olarak değişebilir. Yenidoğan ve süt çocuklarında; ciddi aritmilere sekonder konjestif kalp yetmezliği tablosu, büyük çocuklarda; çarpıntı, göğüs ağrısı ve senkop gibi belirtiler gözlenebilmektedir (7). Yirmi dört saatlik ritim Holter analizi yapılan 450 hastamızın başvuru șikayetlerine göre sıklik sırası; \%48.8 (220/450) çarpıntı, \%37.7 (170/450) göğüs ağrısı ve \%13.3 (60/450) senkop şikayeti vardı. Klıc ve ark.(8) çalışmalarında 24 saatlik ritim Holter analizi yapılan 402 hastada; \%33.6 göğüs ağrısı, \%22.9 çarpıntı, \%7 senkop ve \%31.9 asemptomatik olduklarını bildirmişlerdir. Ancak bizim çalışmamızda yakınması olmayanların 24 saatlik ritim Holter kayıtları çalışmaya alınmadığı için sadece şikayeti olanlarda oran hesaplandı.

Konjenital kalp hastalıkları, kardiyomiyopatiler ve kardiyak cerrahi sonrası gelişen aritmiye bağlı ani ölüm vakaları bildirilmektedir. Ancak yapısal bir anomali olmayan normal kalpte de \%0.02- 
5 oranında iyi huyludan çok ciddi aritmilere kadar çok geniş spektrumda ritim bozuklukları görülebilmektedir (9). Amerikan Kalp Akademisi (ACC) ve Amerikan Kalp Derneği (AHA) 24 saatlik ritim Holter monitorizasyonu için sınıf 1 endikasyon olarak; nedeni belli olmayan senkop, presenkop ya da baş dönmesi ataklarının olması ve açıklanamamış tekrarlayan çarpıntı ataklarının bulunması olarak belirtmişlerdir (10). Çalışmamızda da bu kriterlere uygun olarak öykü, fizik muayene ve EKG ile tam olarak açıklanamayan senkop, göğüs ağrısı ve çarpıntı şikayeti ile gelen hastalarda 24 saatlik ritim Holter kayıtları alınmıştır.

Çocuk yaş grubunda senkop yaygındır, 8-18 yaşları arasındaki çocuk ve ergenlerin \%15-25'nin erişkin yaşa geldiklerinde en az bir senkop atağı geçirdiği görülmüştür. Kız çocuklarında senkop atağı erkeklere göre biraz yüksek gözlenmektedir (11). Hallıoğlu ve ark. (12) çarpıntı, göğüs ağrısı ve senkop yakınması ile başvuran 302 hastada yapmış olduğu çalışmada yaş aralığını 4-17 yıl olarak belirtmişlerdir. Yirmi dört saatlik ritim Holter kayıtları yapılan senkop, göğüs ağrısı ve çarpıntı şikayeti olan olgularımızın yaş ortalamaları literatürdekilerle uyumluydu. Senkop şikayeti olan grubun yaş ortalaması çarpıntısı olanlardan istatistiksel olarak yüksek saptandı ( $p=0.021)$. Göğüs ağrısı olanların yaş ortalamaları senkop ve çarpıntı şikayeti olanlarla benzerdi. Levine'in (13) senkop şikayeti olan 60 olguyu içeren bir çalışmada Kı/Erkek (K/E) oranını 1.2 ve yaş ortalamasını ise $13.5 \pm 3$ yll olarak tespit etmişlerdir. Çalışmamızda geliş şikayetlerine göre K/E oranı 1.14 olup önceki çalışmalarla benzer olduğu görüldü.

Hegazy ve ark. (14) senkop şikayeti olan 1319 hastada yapmış olduğu çalışmada EKO yapılan hastaların 14 tanesinde (\%13.2) patolojik EKO bulguları saptamışlardır. Karamanlı ve ark. (15) çarpıntı şikayeti ile gelen olgularda yapmış olduğu çalışmada 364 hastadan 86'sında (\%23.6) EKO'da patoloji tespit etmișler ve bu 86 hastanın 5'inde EKG'de ve 28'inde 24 saatlik ritim Holter'de aritmi olduğunu göstermişlerdir. Çalışmamıza daha önce bilinen kalp hastalığı olmayan hastalar alınmasına rağmen 450 hastamızın 64'ünde (\%14.2) EKO ile konjenital veya edinsel kalp hastalığı olduğu tespit edildi, ayrıca bu 64 hastanın 37'sinde çarpıntı, 21'inde göğüs ağrısı ve 6'sında senkop yakınması vardı. Patolojik EKO bulguları olan hastalarımııın \%7.8'inde (5/64) EKG'de ve \% 28.1'inde (18/64) 24 saatlik ritim Holter'de aritmi sapandı. Ancak patolojik EKO bulguları olan hastalarımızda küçük septal defektler (atriyal veya ventriküler) veya hafif romatizmal/konjenital kapak hastalığı gibi klinik olarak önemli olmayan kalp problemleri saptandı. Bu nedenle patolojik EKO bulguları ile saptanan aritmiler arasında herhangi bir bağlantı kurulamadı.

Elektrokardiyografi çocuk hastalarda kısa süren veya aralıklı ortaya çıkan aritmileri belirlemede yetersiz kalmaktadır. Bu nedenle 24 saatlik Holter monitorizasyonu aritmiyi tespit etmede ve ritim bozukluğunun başlangıç, bitiş ve süresini değerlendirmede EKG'ye göre daha üstündür (4, 16). Çalışmamızda tüm hastaların EKG'lerinde aritmi sıklığı \%6.6 (30/450) iken 24 saatlik ritim Holter kayıtlarında bu oran \%34.6
(156/450) olarak tespit edildi. Elektrokardiyografi kayıtları normal olan 420 hastanın 134'ünde 24 saatlik ritim Holter'de aritmi tespit edildi. Yirmi iki hastamıda hem EKG'de hem de 24 saatlik ritim Holter'de aritmi olduğu görüldü. Karamanlı ve ark.(15) yaptığı çalışmada elektrokardiyografiyle hastaların \%11.5'inde ( $\mathrm{n}: 42)$ disritmi belirlemişler ve EKG'si normal olan 322 hastanın ise 84'ünde (\%26.1) 24 saatlik ritim Holter kayıtlarında aritmi saptamışlardır. Çalışmamızda EKG'lerde ciddi bir aritmi görülmedi, ancak aritmi görülen EKG'lerin \%30'unda (9/30) SVE ve \%70'inde (21/30) de VES olduğu görüldü. Sonuçlarımızın literatür verilerini destekler nitelikte olduğu görüldü.

Çarpıntı kardiyak aritmilerin en yaygın doktora başvuru sebeplerinden olup, kardiyoloji doktorlarının ayıııcı tanıda zorlandığı şikayetlerdendir. Çarpıntının nedeni iyi huylu olabileceği gibi hayatı tehdit eden aritmiler de olabilir (14). Senkop veya egzersizle ilişkili çarpıntı, hipertrofik kardiyomiyopati veya uzun QT sendromu gibi altta yatan ciddi kalp hastallkları ile ilgili olabilir. Çarpıntı şikayeti ile başvuran pediatrik hastaların \%5.735 'ine 24 saatlik ritim Holter ile tanı konulabilmektedir $(14,17)$. Hallığlu ve ark. (12) yapmış olduğu çalışmada, çarpıntıda \%37.1 oranında aritmi tespit etmişlerdir. Karamanlı ve ark. (15) çalışmalarında çarpıntı ile gelen hastaların \%33'ünde (\%7.1 ciddi ve \%25.9 önemsiz ritim bozukluğu) aritmi olduğunu bildirmişlerdir. Aynı çalışmada en sık SVE ve ikinci sıklıkta VES olduğunu belirtmişlerdir. Çalışmamızda çarpıntı șikayeti olan hastaların \%31.3'ünde (69/220) 24 saatlik ritim Holter kayitlarında aritmi tespit edildi. Aritmiler genel anlamda iyi huylu (VES, SVE) olmalarına rağmen üç hastada non-sustained (kısa süreli) SVT görülürken, bir hastada non-sustained VT ve yine bir hastada sustained (uzun süreli) VT görüldü. Çarpıntı şikayeti ile gelen olgularımızda görülen ritim bozuklukları önceki çalışmalarla benzer saptandı.

Göğüs ağrısı ile çocuk acil servise başvuruların \%0.5-5'nin kardiyak sebeplere bağlı olduğu belirtilmektedir (18). Ekstra atımlar göğüste bir rahatsızlık hissi oluşturabilir ve bu da çocuklar tarafından ağı olarak tanımlanabilir. Aynı zamanda aritmiler de neden oldukları iskemi sonucunda göğüs ağrısı oluşturabilirler $(18,19)$. Akut başlangıçlı, egzersizle ortaya çıkan, uykudan uyandıran, solunum sıkıntısı, çarpıntı, baş dönmesi, presenkop ve senkopun eșlik ettiği göğüs ağrları kardiyak etkenler açısından uyarıcı olmalıdır (20). Hallığlu ve ark. (12) yapmış olduğu çalışmada göğüs ağrısında aritmi sıklığını \%23.5 olarak tespit etmişlerdir. Kervancıoğlu ve ark. (19) göğüs ağrısı ile başvuran hastaların 24 saatlik ritim Holter monitorizasyonunda; üç hastada sık SVE, iki hastada sinüs taşikardisi, bir hastada ventriküler taşikardi ve bir hastada da sık tekli VES saptamıșlardır. Çalışmamızda göğüs ağrısı ile gelen hastalarda 24 saatlik ritim Holter'de aritmi sıklığı \%32.9'du (56/170); en sIk VES tespit edilirken bir hastada non-sustained VT saptandı. Senkop geçiren erişkin hastalarda yapılan çalışmalarda 24 saatlik ritim Holter'in tanı değerinin \%4-8.6 olduğu belirtilmektedir. Çocuklarda bu konu ile ilgili yapılan çalışmaların 
kısıtı sayıda olduğu bildirilmektedir (14,21). Genel olarak senkop nedenlerinin sadece \%2-6'sı kardiyak kökenlidir. Nadir olmasına rağmen, pediatrik senkopun kardiyak nedenleri hayati tehlike oluşturabilir (11). Hegazy ve ark.(14) kardiyak nedene bağlı senkop oranını \%11.5 ve aritmi oranını da \%5.5 olarak saptamışlardır. Çalışmamızda 60 senkoplu hastanın 31'inde (\%51.6) aritmi tespit edildi. Senkoplu hastalarda saptadığımız aritmiler genel olarak VES ve SVE olduğu görülmekle beraber bir hastada non-sustained VT saptandı. Ne varki VT dışındaki aritmilerin senkop ile ilişkili olmadıkları düşünüldü. Çarpıntı ve göğüs ağrısı ile başvuranlarda aritmi görülme sıklığı benzer iken senkop șikayeti olanlarda her iki guruba göre anlamlı olarak daha yüksekti $(p=0.011)$.

Sonuç olarak; çarpıntı, göğüs ağrısı ve senkop yakınması ile başvuran çocuklarda ritim düzensizliklerini tespit etmede literatürde olduğu gibi 24 saatlik ritim Holter monitörizasyonun klasik EKG'ye göre daha başarıı olduğu görülmüştür. Dahası EKG ile tespit edilen aritmilerin klinik olarak önemi olmayan aritmiler olduğu görülürken 24 saatlik ritim Holter'de klinik olarak önemsiz ritim düzensizlikleri yanında üç hastada SVT ve dört hastada VT olduğu saptanmıştır. Yakınması olan hastalardan alınan anamnez, yapılan fizik muayene ve EKG incelemeleri ile nedeni tam olarak açıklayamıyorsak veya ciddi bir aritmi olabileceğinden şüpheleniyorsak 24 saatlik ritim Holter monitörizasyonu yapılmasının istenmeyen sonuçlarla karşılaşılmaması için önemli olduğunu düşünmekteyiz.

\section{KAYNAKLAR}

1. Patel S, Yazdi F, Perez M. Management of Pediatric Chest Pain, Palpitations, Syncope, and Murmur Presenting to the Emergency Department. Clinical Pediatric Emergency Medicine 2018;19:32838.

2. Premkumar S, Premkumar S, Sangaralingam T. Clinical Profile of Cardiac Arrhythmias in Children Attending the Out Patient Department of a Tertiary Paediatric Care Centre in Chennai. J Clin Diagn Res 2016;10:6-8.

3. Yiğit F. Ambulatuar Elektrokardiyografik Kayıt. Türk Disritmi, Pacemaker ve Elektrofizyoloji Dergisi 2007;5:109-23.

4. Alexander ME, Berul Cl. Ventricular arrhythmias: when to worry. Pediatr Cardiol 2000;21:532-41.

5. Niwa K, Warita N, Sunami Y, Shimura A, Tateno T, Sugita K.Prevalence of arrhythmias and conduction disturbances in large population-based samples of children. Cardiol Young 2004;14:6874.

6. Wren C, O'Sullivan JJ, Wright C. Sudden death in children and adolescents. Heart 2000;83:410-3.

7. Sekar RP. Epidemiology of Arrhythmias in Children. Indian Pacing Electrophysiol J 2008;8:8-13.

8. Kılıç Z, Karataş Z, Uçar B. Çocuklarda Retrospektif Üç Yıllık Holter Monitorizyonu Deneyimi. Yeni Tıp Dergisi 2012;29:95-9.

9. Clausen H. Theophilus T, Jackno K, Babl FE. Paediatric arrhythmias in the emergency department. Emerg Med J 2012;29:732-7.

10. Blomström-Lundqvist C, Scheinman MM, Aliot EM, Alpert JS, Calkins H, Camm AJ, et al. ACC/AHA/ESC Guidelines for the
Management of Patients With Supraventricular Arrhythmias Executive Summary A Report of the American College of Cardiology/American Heart Association Task Force on Practice Guidelines and the European Society of Cardiology Committee for Practice Guidelines (Writing Committee to Develop Guidelines for the Management of Patients With Supraventricular Arrhythmias). Circulation 2003;108:909-1871.

11. Black KD, Seslar SP, Woodward GA. Cardiogenic Causes of Pediatric Syncope. Clinical Pediatric Emergency Medicine 2011;12:266-77.

12. Hallıoğlu O, Giray D, Karpuz D, Özyurt A. Çarpıntı, göğüs ağrısı ve senkop yakınmalı çocuklarda Holter monitorizasyon sonuçları: Sekiz yıllık deneyim. Mersin Üniversitesi Sağlık Bilim Dergisi 2017;10:82-7.

13. Levine MM. Neurally mediated syncope in children: Results of tilt testing, treatment and longterm follow-up. Pediatr Cardiol 1999;20:331-5.

14. Hegazy RA, Ltfy WN. The value of Holter monitoring in the assessment of pediatric patients. Indian Pacing Electrophysiol $\mathrm{J}$ 2007;7:204-14.

15. Karamanlı G, Kibar Gül AE, Azak E, Gürsu HA, Çetin Ii. Çocukluk Çağında Çarpıntı Yakınması ile Başvuran Hastalarda Ritim Holter Monitorizasyon Sonuçlarının Değerlendirilmesi; Türkiye Çocuk Hastalıkları Dergisi 2020:1-8 (Basım aşamasında) DOI:10.12956/ tchd.524017.

16. Kennedy $H$. Use of long-term (Holter) Electrocardiographic recordings. In: Zipes D, Jalife J (eds). Cardiac Electrophysiology from cell to bedside. 3rd ed. WB. Saunders; 2000:717-30.

17. Ruby F, River RF, Chambers P, Ceresnak RS. Evaluation of Children With Palpitations. Clinical Pediatric Emergency Medicine 2011;12:278-88.

18. Drossner DM, Hirsh DA, Sturm JJ, Mahle WT, Goo DJ, Massey R, et al. Cardiac disease in pediatric patients presenting to a pediatric ED with chest pain. Am J Emerg Med 2011;29:632-48.

19. Park MG. Child with chestpain. In: Park MK. (ed). Pediatric Cardiology for Practitioners, 6th ed. Philadelphia: Elseviers Saunders 2014:505-15.

20. Kervancıoğlu M, Devecioğlu C, Okur N. Çocuk Kardiyolojisi Polikliniğine Göğüs Ağrısı Yakınmasıyla Başvuran Hastaların Değerlendirilmesi. Dicle Tıp Dergisi 2005;32:196-200.

21. Uysal F, Bostan ÖM, Çetinkaya F, Deniz T, Çil E. Çocuklarda Senkop: Ritim Holter Monitörizasyonu Gerekli mi? Güncel Pediatri Dergisi 2016;14:124-8. 